\title{
Metabolic rate of blue mussels (Mytilus edulis) under varying post-harvest holding conditions
}

\author{
Sara BARRENTO ${ }^{1,2, a}$, Ingrid LuPATSCH ${ }^{1}$, Alex KEAY $^{1}$ and Gyda CHRISTOPHERSEN ${ }^{3}$ \\ ${ }^{1}$ Centre for Sustainable Aquaculture Research, Swansea University, SA2 8PP, Swansea, UK \\ 2 CIMAR/CIIMAR, Interdisciplinary Centre for Marine and Environmental Research, University of Porto, \\ Rua dos Bragas 289, 4050-123 Porto, Portugal \\ 3 The National Institute of Technology, P.O. Box $141 \varnothing$ kern, NO-0509 Oslo, Norway
}

Received 12 November 2012; Accepted 7 April 2013

\begin{abstract}
The mussel (Mytilus edulis) is successfully grown in aquaculture in Europe. Mussels are usually sold live and wet storage is becoming more common. In this study, oxygen demand and ammonia excretion were assessed at increasing water temperatures and different post-harvest situations. This information was used to calculate minimal flow rates per unit biomass of live mussels sufficient to keep oxygen above $5 \mathrm{mg} \mathrm{L}^{-1}$ or $50 \%$ saturation, and avoid accumulation of ammonia in commercial wet storage. In this study, rope-grown mussels were kept out of water for $8 \mathrm{~h}$ to simulate harvesting conditions and then re-immersed in holding tanks at 5,10 and $15^{\circ} \mathrm{C}$. Oxygen and ammonia concentrations were measured immediately after mussels were re-immersed $(0 \mathrm{~h})$, after $6 \mathrm{~h}$ and then every day for 3 days. After this period, the mussels were again kept out of water for $48 \mathrm{~h}$ to simulate long-distance transport and once again re-immersed for the same period as before. In the first $6 \mathrm{~h}$ after re-immersion, the oxygen consumption was between 7.5 and $12.2 \mu \mathrm{mol} \mathrm{g}^{-1} \mathrm{~h}^{-1}$ (dry flesh) and after this period it decreased to a standard level of around $4.0 \pm 0.9 \mu \mathrm{mol} \mathrm{g}^{-1} \mathrm{~h}^{-1}$ and was independent of temperature. There were no major differences in oxygen consumption between mussels having spent 8 and $48 \mathrm{~h}$ out of water at any of the subsequent water temperatures used for re-immersion. In contrast, the ammonia excretion showed greater differences according to temperature and time out of water. Ammonia excretion was lowest at $5{ }^{\circ} \mathrm{C}\left(<0.01 \mu \mathrm{mol} \mathrm{g}{ }^{-1} \mathrm{~h}^{-1}\right)$. The implications of these results for the industry and authorities are discussed considering the water flow rate, depuration specifications and energy costs.
\end{abstract}

Keywords: Ammonia / oxygen / holding / air exposure / temperature / physiology / live mussel / bivalve mollusc

\section{Introduction}

Mussel aquaculture is an important industry worldwide and Mytilus sp. is the third most popular mollusc in cultivation (FAO 2012). In Europe, Spain has the highest mussel production (198531 tonnes), followed by France (76823 t), Italy $(76800 \mathrm{t}$ ) and The Netherlands $(45618 \mathrm{t}$ ) (data from EUROSTAT 2009). Bivalve species such as mussels can survive for extended periods out of water and those for human consumption are traded as live animals. The increased production and the development of rapid ground and air transport have improved the supply of this live product to markets worldwide, but distribution and sale of live mussels remains a complex issue.

Following harvest, cultured mussels are washed, declumped and debyssed. If bacterial loads in the harvesting area are above the level permitted by the legislation, which varies between different countries, mussels must also be depurated or relayed before going to market (Lee et al. 2008;

a Corresponding author: s.i.barrento@swansea.ac.uk
Oliveira et al. 2011). Depuration is a re-watering process of reimmersion in clean water that promotes the purging of some bacteria from mussels. Mussels are held in an approved system for 12 to $42 \mathrm{~h}$ depending on local regulations and are then once again declumped, debyssed, packed and transported (Muniain-Mujika et al. 2002; Love et al. 2010). Transport out of water can last between 24 and $48 \mathrm{~h}$ and, in some cases, mussels are once again re-immersed after transport. When out of water, mussels cannot continue to excrete their metabolic products such as ammonia. They also face the difficulty of maintaining aerobic respiration and are morphologically ill-equipped to do so (poor, open circulation and the lack of a respiratory pigment), and their behavioural responses to regulate water loss concomitantly impair gaseous exchanges. The oxygen consumption rates of bivalve molluscs when out of water are invariably less than the minimum rates measured when submerged (Sadok et al. 1999). Also, during postharvest practices, mussels can experience fluctuating temperatures, sunlight and other bright lights, wind or drafts, handling and physical damage, and poor water quality during holding, conditioning and depuration. As a result, during transport and 
storage, mussels might suffer byssus damage, intravalvular liquid loss and decline in condition, quality and survival ability (Dare 1974; Slabyj and Hinkle 1976; Harding et al. 2004).

Most traders are aware of these problems and mussels are therefore usually shipped as soon as possible after packing. However, due to the logistics of harvesting in remote locations, transportation complications can arise that prevent the mussels from being taken to market immediately (Wyatt et al. 2013). As a result, they may need to be held in water in holding facilities until transportation is possible. Short re-immersion periods after post-harvest practices have proven beneficial, as survival of mussels was seen to be $30 \%$ better after a $12 \mathrm{~h}$ re-immersion period and $50 \%$ better after $48 \mathrm{~h}$ re-immersion (Slabyj and Hinkle 1976; Prochazka and Griffiths 1991). However, it is expected that an extended time in holding would cause an increase in mortalities. Wyatt et al. (2013) suggested that extended holding has a negative effect on the overall physiology of the blue mussel, M. edulis, and it was concluded that one month should be the maximum time spent in ambient wet-storage. Use of recirculation systems with water re-use and treatment can reduce water needs considerably compared with flow-through systems (Bradley and Grant 2002; Lucas and Southgate 2012). The design of holding and conditioning systems is governed by a number of factors, among which economics is of major importance. Systems also need to be practical to use and manage, and designed to suit the biological requirements of animal and food safety regulations. In some countries, the national regulations are very restrictive and detailed regarding water quality and general holding conditions for bivalves (Lee et al. 2008). Usually, oxygen, ammonia and temperature are crucial factors in maintaining a healthy holding system.

For intertidal mussels, a range of biological information is now available (Coleman 1973; Jokumsen and Fyhn 1982; Zwaan et al. 1983; Sadok et al. 1995; Marsden and Weatherhead 1998; Helmuth and Hofmann 2001; Gosling 2003; Honkoop et al. 2003; Fitzhenry et al. 2004; Chandurvelan et al. 2013) that can be potentially applied for the design of systems and development of best practice. Literature regarding the physiology of rope-grown mussels under stressful conditions is almost non-existent. To prevent mortalities, economic losses, and ultimately the waste of an important, but finite resource, there is therefore a need to design specific trials simulating post-harvest practices that stimulate the mussels' physiological response.

In this study, water quality parameters affecting survival and quality of live rope-grown Mytilus edulis during wetstorage, such as oxygen demand and ammonia excretion, were assessed at different water temperatures and in different postharvest situations to simulate various scenarios commonly found in the industry. This information was used to calculate the minimal flow rates per unit biomass of live mussels sufficient to keep oxygen concentration above the minimum limit of $5 \mathrm{mg} \mathrm{L}^{-1}$ and avoid strong accumulation of ammonia for commercial wet storage. A comparison of these rates was made with current depuration holding system specifications. This information is crucial to keeping mussels alive and in good condition during wet storage in simple to use, inexpensive systems running without biofilters.

\section{Materials and methods}

\subsection{Maintenance conditions}

Rope-grown blue mussels (Mytilus edulis) were harvested from a local producer located in Swansea Docks (latitude $51^{\circ}$ $37^{\prime} \mathrm{N} /$ longitude $3^{\circ} 55^{\prime} \mathrm{W}$ ), Swansea, Wales, UK. The harvesting production site had an Escherichia coli load of less than $20 \mathrm{E}$. coli per $100 \mathrm{~g}$ at the time of harvest according to shellfish monitoring results published by CEFAS (2012). This corresponds to a Class A $(\leqslant 230$ E. coli $/ 100 \mathrm{~g})$ harvesting site (shellfish suitable for direct human consumption) according to Regulation (European Commission) 853/2004 ${ }^{1}$.

Mussels measuring $57 \pm 1 \mathrm{~mm}$ in length were harvested in January 2012 and immediately transported to the laboratory in a cooling box without water. The temperature inside the box was $9.1{ }^{\circ} \mathrm{C}$. Once in the laboratory, these mussels were kept in the box with ice on top and a lid for a total of $8 \mathrm{~h}$, to simulate a normal harvest day (temperature inside the box $2-4{ }^{\circ} \mathrm{C}$ ). After this period, the mussels were placed in tanks measuring $31 \times 40.6 \times 20 \mathrm{~cm}$. A total of $1 \mathrm{~kg}$ mussels ( $n=58$ to 60 mussels) was stocked in each of three tanks, with a total volume of $20 \mathrm{~L}$ seawater in each; thus providing three replicate treatments for each temperature trial. Water samples were collected for ammonia analyses and oxygen was measured immediately after re-immersion $(0 \mathrm{~h})$, after $6 \mathrm{~h}$ and then periodically after 24,48 and $72 \mathrm{~h}$.

After this re-immersion period, simulation of transport was carried out for $48 \mathrm{~h}$, with mussels in $1 \mathrm{~kg}$ net bags in a cool box covered with ice and placed in a cold room. Temperature during this simulated transport was monitored every minute using data loggers. The temperature was measured inside three mussels using DS1921 iButton data loggers ${ }^{\complement}$ Copyright 2001 Revolution Education Ltd, which are small enough $(170 \mathrm{~mm}$ in diameter and $60 \mathrm{~mm}$ height) to fit within individual mussels without disturbing them. Preliminary trials showed that the loggers could be inserted inside mussels by opening a small gap between their valves. The core temperature of mussels during simulated transport was $1.5 \pm 0.5^{\circ} \mathrm{C}$.

After this period out of water, mussels were returned to water at $5{ }^{\circ} \mathrm{C}$, and oxygen and ammonia were measured after immersion $(0 \mathrm{~h})$, again after $6 \mathrm{~h}$ and then periodically as before (Fig. 1). The same procedure was repeated in February at a water temperature of $11^{\circ} \mathrm{C}$ and in May at $15^{\circ} \mathrm{C}$. The water temperature in the immersion tanks was maintained at $5.4 \pm 0.4{ }^{\circ} \mathrm{C}$ in January, $11.3 \pm 0.1{ }^{\circ} \mathrm{C}$ in February and $14.7 \pm 0.2{ }^{\circ} \mathrm{C}$ in May. Salinity was kept at $34 \mathrm{ppm}$. Mortality was evaluated by tapping on any bivalve shells that were gaping and observing mussel closure. Any mussel still gaping after tapping was considered dead (Pastoriza et al. 2004). There were no mortalities

\footnotetext{
${ }^{1}$ Regulation (EC) No. 853/2004 of the European Parliament and of the Council of 29 April 2004 laying down specific hygiene rules for food of animal origin. Corrected and re-published in Off. J Eur. Union, L 226, 25.6.2004, p. 22.

Regulation (EC) No 854/2004 of the European Parliament and of the Council of 29 April 2004 laying down specific rules for the organisation of official controls on products of animal origin intended for human consumption. Corrected and re-published in Off. J. Eur. Union, L 226, 25.6.2004, p. 83.
} 


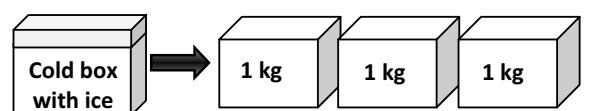

Harvest $8 \mathrm{~h} \quad$ Re-immerse and check $\mathrm{O}_{2}$ and Out of water ammonia after: 0, 6, 24 and $72 \mathrm{~h}$
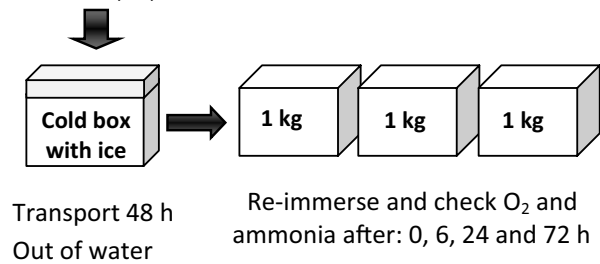

Fig. 1. Diagram summarizing the experimental design.

during the trials. Mussels were not fed during the experiments, but were supplied with algae in between trials.

Mussel dry weight was determined by removing the fresh mussel flesh from the shells and weighing it. The flesh was then dried overnight at $105{ }^{\circ} \mathrm{C}$. Moisture content of flesh was on average $20 \%$ and the total fresh weight of $1 \mathrm{~kg}$ live mussels (including interstitial water) corresponded to $59.9 \pm 0.4 \mathrm{~g}$ dry flesh weight (DW).

\subsection{Physiological measurements}

To estimate the oxygen consumption and ammonia excretion rates, mussels were placed in tanks that functioned as respirometry chambers. Oxygen concentration was measured with a hand-held oxygen probe (Handy Polaris $® O x y g u a r d)$, calibrated according to the manufacturers' specifications. Salinity was measured with a refractometer and the data entered into the oxygen probe. To measure the oxygen consumption of the mussels, oxygen content of the seawater was measured at the inlet before the water flow was switched off for $2 \mathrm{~h}$. Oxygen was then measured every $30 \mathrm{~min}$. During this $2 \mathrm{~h}$ period, the oxygen saturation never decreased below $70 \%$. Depending the temperature, oxygen decreased between 10 and $25 \%$ compared with the initial values. During the incubation, a custom-built lid was used to cover the water surface to prevent any oxygen diffusion from the air. For all treatments, mussels were visually inspected to check if they had opened once re-immersed. It was observed that all mussels opened their valves within 3 min of being put in the water.

The oxygen consumption $(O C)$ rate $\left(\mu \mathrm{mol} \mathrm{g} \mathrm{g}^{-1} \mathrm{~h}^{-1}\right)$ was calculated as follows:

$$
O C=\Delta O \times V / T w / \Delta t
$$

where $\Delta O$ is the difference between the initial and final oxygen concentrations ( $\mu \mathrm{mol} \mathrm{g}^{-1}$ ) of the measurement period, $V$ is the volume in each tank $(20 \mathrm{~L}), T w$ is the total dry weight $(\approx 60 \mathrm{~g})$ and $\Delta \mathrm{t}$ is the time interval $(2 \mathrm{~h})$.

For ammonia analyses, three water samples were taken from each tank using 50-ml universal flasks. The samples were taken at the same time as the oxygen measurements but were frozen before the analyses. The system used in the analysis of ammonia was a 2-channel segmented flow analyser supplied by Seal Analytical (AutoAnalyzer II). The ammonia measurement method used the modified Berthelot reaction, in which ammonia reacts with sodium salicylate and the cyanurate reagent to form a blue green complex that can be detected at $660 \mathrm{~nm}$ light wavelength.

The following equation was used to calculate the total ammonia as nitrogen excretion rate:

$$
A E=\Delta A \times V / T w / \Delta t
$$

where $A E$ is the ammonia excretion rate $\left(\mu \mathrm{mol} \mathrm{g} \mathrm{g}^{-1} \mathrm{~h}^{-1}\right), \Delta A$ is the difference between the initial and final ammonia concentrations $\left(\mu \mathrm{mol} \mathrm{g}^{-1}\right)$ of the measurement period; the remaining parameters are the same as given above for oxygen consumption rate.

The atomic ratio of oxygen to nitrogen $(\mathrm{O} / \mathrm{N}$ atomic ratio) was calculated based on the oxygen uptake and ammonium excretion rates, expressed in atomic equivalents for $1 \mathrm{~g}$ DW mussel, according to the formula: $\mathrm{O} / \mathrm{N}=\left(\mu \mathrm{g} \mathrm{O}_{2} \mathrm{~h}^{-1} / 16\right) /\left(\mu \mathrm{g} \mathrm{NH} \mathrm{h}^{-1} / 14\right)$, after Widdows and Johnson (1988).

\subsection{Statistics}

Results were expressed as mean values \pm standard deviation. Analysis of variance (ANOVA) tests were used to test the effects of time and temperature separately for the following variables: oxygen consumption and ammonia excretion. ANOVA was followed by multiple comparison tests (Tukey HSD). If transformed data did not meet ANOVA assumptions, non-parametric analysis of variance (Kruskall-Wallis) was performed, followed by non-parametric multiple comparison tests (Dunn). Analyses were carried out to test differences between temperatures or different lengths of incubation period within each temperature.

\section{Results}

Oxygen consumption had a similar pattern whether mussels were re-immersed after 8 or $48 \mathrm{~h}$ out of water (Fig. 2). During the first $6 \mathrm{~h}$, the oxygen consumption was high (between 7.5 and $12.2 \mu \mathrm{mol} \mathrm{g}-1 \mathrm{~h}^{-1}$ at 5 and $11{ }^{\circ} \mathrm{C}$, respectively) and after this period it decreased to a standard level (around $4.0 \pm 0.9 \mu \mathrm{mol} \mathrm{g}{ }^{-1} \mathrm{~h}^{-1}$, Fig. 2 top). There were no significant differences between oxygen consumption at 11 and $15{ }^{\circ} \mathrm{C}$. Additionally, there were no significant differences between 8 and $48 \mathrm{~h}$ out of water, except immediately after a return to water at $5{ }^{\circ} \mathrm{C}$. In this case, oxygen consumption was greater after $48 \mathrm{~h}$ out of water then after $8 \mathrm{~h}(10.1 \pm 0.9$ and $7.5 \pm 0.8 \mu \mathrm{mol} \mathrm{g}^{-1} \mathrm{~h}^{-1}$, respectively).

Ammonia excretion was different among the three water temperatures and between the different lengths of time out of water. Ammonia excretion was greater at higher temperatures and after a longer period out of water ( $48 \mathrm{~h}$ ). Immediately after re-immersion at $15^{\circ} \mathrm{C}$, ammonia concentration was greater $\left(2.1 \pm 0.3 \mu \mathrm{mol} \mathrm{g}^{-1} \mathrm{~h}^{-1}\right)$ than at $11^{\circ} \mathrm{C}\left(0.7 \pm 0.2 \mu \mathrm{mol} \mathrm{g}^{-1} \mathrm{~h}^{-1}\right)$ and $5{ }^{\circ} \mathrm{C}\left(<0.01 \mu \mathrm{mol} \mathrm{g}^{-1} \mathrm{~h}^{-1}\right.$, Fig. 3$)$. Following $8 \mathrm{~h}$ out of water, ammonia excretion at $5{ }^{\circ} \mathrm{C}$ was delayed and only after $24 \mathrm{~h}$ was there an overshoot. Ammonia excretion then decreased to levels below $0.01 \mu \mathrm{mol} \mathrm{g}-1 \mathrm{~h}^{-1}$ after $72 \mathrm{~h}$ (data not shown). After $48 \mathrm{~h}$ of air exposure, the pattern was similar, but at 

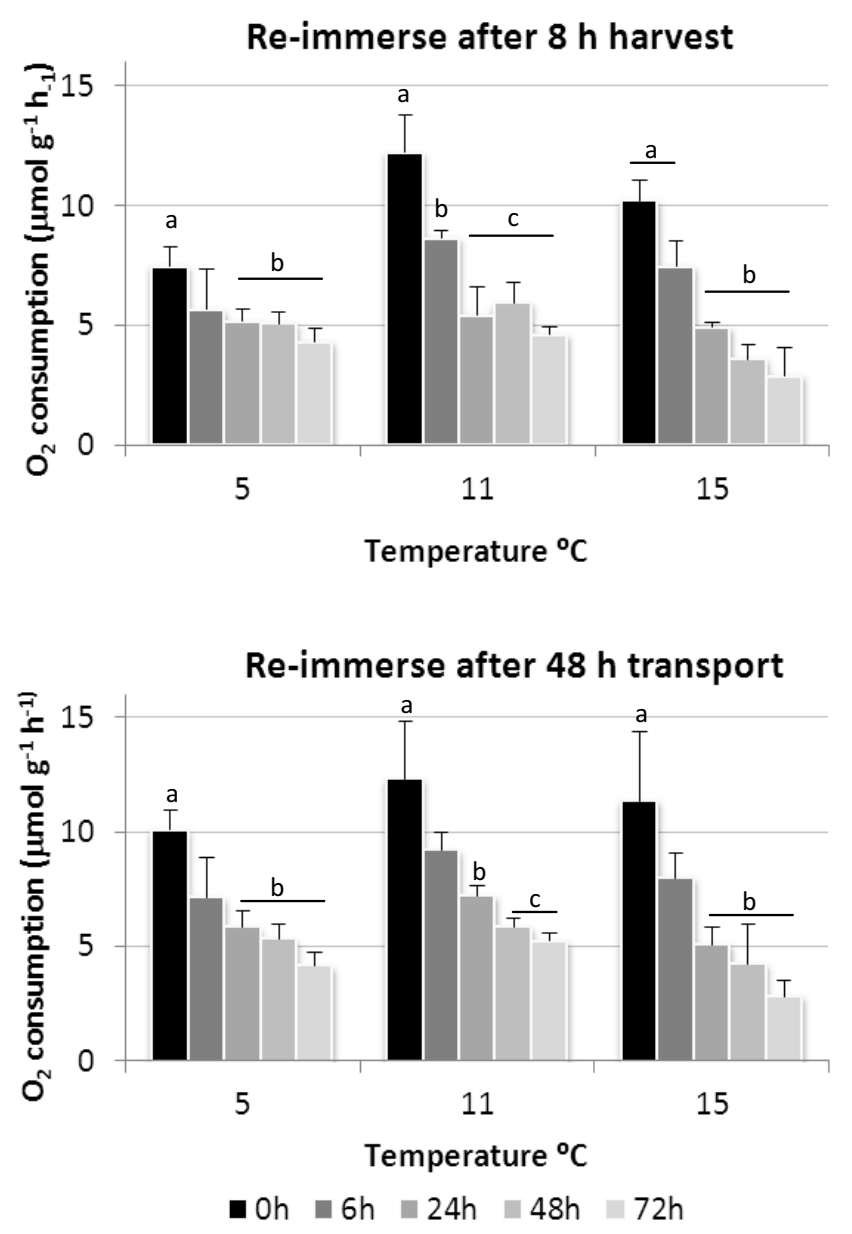

Fig. 2. Oxygen consumption ( $\mu \mathrm{mol} \mathrm{g}^{-1} \mathrm{~h}^{-1}$ ) of mussels immediately after re-immersion $(0 \mathrm{~h})$, and then after 6, 24, 48 and $72 \mathrm{~h}$ at different water temperatures: 5,11 and $15{ }^{\circ} \mathrm{C}$. Top: harvest simulation, $8 \mathrm{~h}$ out of water, Bottom: long transport simulation, $48 \mathrm{~h}$ out of the water. For each temperature, different letters represent significant differences between lengths of time out of water.

5 and $11{ }^{\circ} \mathrm{C}$ the excretion after $48 \mathrm{~h}$ was greater than after $8 \mathrm{~h}$ of air exposure. Comparing ammonia excretion of mussels at different temperatures, no difference was observed between 11 and $15^{\circ} \mathrm{C}$ (Fig. 3 bottom).

\section{Discussion}

Results of oxygen consumption and ammonia excretion of rope grown mussels re-immersed after different post-harvest steps out of water are crucial for managers and the authorities alike. This research was carried out in order to determine appropriate minimum water flow rates to avoid a critical decline of oxygen concentrations and build-up of ammonia, which can affect both survival and the smell of mussels. This information is crucial for managers seeking low cost solutions to keep mussels alive, while authorities are concerned with consumer perception of quality (smell, freshness appearance), animal welfare and food safety.

Temperature is one of the exogenous factors regulating the metabolism of ectothermic organisms, and its influence on the
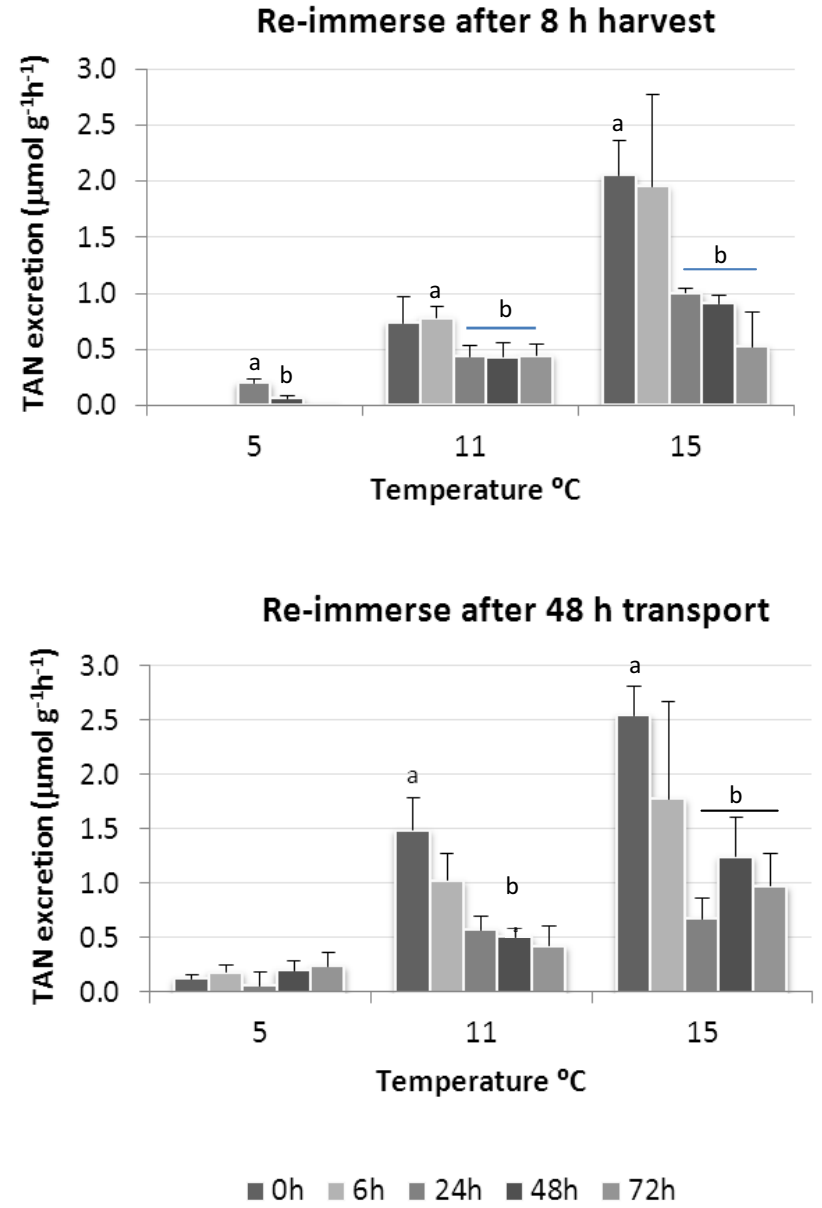

Fig. 3. Ammonia excretion $\left(\mu \mathrm{mol} \mathrm{g} \mathrm{g}^{-1} \mathrm{~h}^{-1}\right)$ of mussels immediately after re-immersion $(0 \mathrm{~h})$, and then after $6,24,48$ and $72 \mathrm{~h}$ at different water temperatures: 5,11 and $15{ }^{\circ} \mathrm{C}$. Top: harvest simulation, $8 \mathrm{~h}$ out of water, Bottom: long transport, $48 \mathrm{~h}$ out of the water. For each temperature, different letters represent significant differences between lengths of time out of water.

rates of oxygen consumption, feeding, and nitrogen excretion in temperate species of marine bivalves and has been studied extensively, see reviews by Newell and Branch (1980) and Gosling (2003). In this study, mussels were not fed and so the changes observed were only related to oxygen consumption and ammonia excretion.

The respiration rate obtained in this study at $5{ }^{\circ} \mathrm{C}$ was similar to the respiration rate of $7 \mu \mathrm{mol} \mathrm{g}^{-1} \mathrm{~h}^{-1}$ obtained in January by Jansen et al. (2012), although the values obtained in June in this previous study were much higher, at $34 \mu \mathrm{mol} \mathrm{g}^{-1} \mathrm{~h}^{-1}$, than the highest respiration rates obtained in the present study at 11 and $15^{\circ} \mathrm{C}$ following re-immersion after $48 \mathrm{~h}$ out of water, which were 12.3 and $11.4 \mu \mathrm{mol} \mathrm{g}^{-1} \mathrm{~h}^{-1}$, respectively. These results might be due to starvation or physiology of mussels in different seasons.

Our results showed that, in the first $6 \mathrm{~h}$ after reimmersion in water, mussel oxygen consumption was high, before decreasing to a standard level. This low rate of oxygen consumption was compared to the standard (basal) rate identified by Bayne (1973) at these three temperatures. According to these authors, in the absence of food, oxygen 
consumption declines to a steady state condition which varies with temperature and is typical of an animal with its shell valves open but showing minimal feeding activity. At 5, 10 and $15{ }^{\circ} \mathrm{C}$ the standard oxygen consumption rates are 6.7, 8.0 and $9.8 \mu \mathrm{mol} \mathrm{g}^{-1} \mathrm{~h}^{-1}$, respectively (Bayne 1973). In the present study, after $48 \mathrm{~h}$, mussels showed oxygen consumption of $5.1,6.0$ and $3.6 \mu \mathrm{mol} \mathrm{g}-1 \mathrm{~h}^{-1}$ at 5,11 and $15^{\circ} \mathrm{C}$, respectively. These values are much lower than the standard level previously calculated by Bayne et al. (1973) and the oxygen consumption rate obtained by Chandurvelan et al. (2013) after $24 \mathrm{~h}$ simulated transport in air. Such low values are probably a combination of temperature and the fact that the animals are not actively feeding, and are in agreement with results obtained by Handå et al. (2012), where M. edulis on low feeding regimes had lower oxygen consumption.

The initial oxygen debt has been shown for other bivalve species. Moon and Pritchard (1970) recorded increased oxygen uptake by $M$. californianus after 6 or $12 \mathrm{~h}$ air exposure, while Bayne et al. (1976) calculated an apparent cumulative oxygen debt when this species was exposed to air. Boyden (1972) suggested that inflated rates of oxygen uptake following air exposure may be caused by hyperactivity associated with excretion and the "flushing out" of ammonia from the body as the animal is re-immersed. This is unlikely to account for the entire apparent oxygen debt. The sudden temperature changes that occurred when the mussels were transferred from the ice box to the tank, may have triggered an initial oxygen consumption overshoot. After this first initial $6 \mathrm{~h}$ of re-immersion, oxygen consumption was temperature independent. This is in agreement with the fact that the standard rate is relatively independent of temperature, which allows intertidal M. edulis to better cope with times of stress, such as those with high temperature and low food availability experienced during aerial exposure in summer (Gosling 2003).

There is considerably less information available on the factors that influence the rate of ammonia excretion than there is on rate of oxygen uptake. It is well known that during exposure to air, mussels continue to produce ammonia, which accumulates in the fluid trapped in the mantle cavity (Gosling 2003). Upon re-immersion, bivalves typically show a distinct overshoot of ammonia (Bayne 1976; de Vooys and de Zwaan 1978; Shick et al. 1988). This ammonia peak was also observed in the present study, except when mussels were re-immersed at $5{ }^{\circ} \mathrm{C}$ after $8 \mathrm{~h}$ out of water. In this case, ammonia overshoot was only measured after $48 \mathrm{~h}$. Sadok et al. (1999) studied the effects of starvation and emersion on the ammonia effluxes of intertidal $M$. edulis. These authors did not observe an ammonia overshoot immediately after re-immersion and concluded that this could be a strategy used by intertidal mussels to conserve energy by conserving ammonia, and suggested that some ammonia utilisation occurred during exposure to air.

Our study has also shown that mussels subjected to the same period out of water, under the same environmental conditions, had a higher ammonia excretion when re-immersed at higher temperatures. This indicates that the ammonia excretion is not just a result of accumulated ammonia during air exposure, but also the result of a higher metabolism when mussels are re-immersed at higher temperatures. According to Bayne (1976), the rate of ammonia excretion by M. edulis increases with rise in temperature and does not acclimate. The variation in the ammonia excretion rate obtained at 5 , 11 and $15{ }^{\circ} \mathrm{C}$ in this study matches the seasonal variations reported by Jansen et al. (2012), where total ammonia nitrogen (TAN) release varied significantly between $0.3 \pm 0.1$ and $2.2 \pm 0.3 \mu \mathrm{mol} \mathrm{g}^{-1} \mathrm{~h}^{-1}$, with highest values in summer.

Rates of ammonia excretion of mussels are extremely variable, which is not surprising in view of the marked seasonal changes in nutrient storage and utilization of reserves. Bayne and Scullard (1977) reported seasonal differences in the rates of ammonia excretion by M. edulis: $0.5 \mu \mathrm{mol} \mathrm{g} \mathrm{g}^{-1} \mathrm{~h}^{-1}$ in winter, 2.5 in spring, 2.1 in summer and 0.4 in autumn. Values for the excretion rate of $M$. edulis also vary considerably depending on animal size, temperature, ration level and salinity. Sadok (1995) reported an M. edulis ammonia excretion rate of $0.64 \mu \mathrm{mol} \mathrm{g}{ }^{-1} \mathrm{~h}^{-1}$ at $10{ }^{\circ} \mathrm{C}$, which is similar to the values obtained in the present study after re-immersion.

The ratio, in atomic equivalents, of oxygen consumed to nitrogen excreted can provide an index of the balance between rates of catabolism of protein, carbohydrate and lipid substrates in an animal's tissues. If the amino acids resulting from protein catabolism are de-aminated, and the resulting ammonia is excreted while the carbon skeletons of the amino acids are completely oxidised, the theoretical minimum for the $\mathrm{O} / \mathrm{N}$ atomic ratio is about 7 , signifying solely protein catabolism. Higher values for $\mathrm{O} / \mathrm{N}$ indicate increased catabolism of carbohydrate and/or lipid. In this study, the $\mathrm{O} / \mathrm{N}$ ratio was always above 7 except for mussels after 48 and $72 \mathrm{~h}$ re-immersion at $15{ }^{\circ} \mathrm{C}$. Also, the mean $\mathrm{O} / \mathrm{N}$ ratio declined with increasing temperature, indicating that protein rather than carbohydrate and lipid was used to meet the increasing demand for energy. This change in ratio was supported by a significantly higher ammonia excretion, which was not accompanied by significant oxygen consumption, thus lowering the $\mathrm{O} / \mathrm{N}$ ratio at 11 and $15^{\circ} \mathrm{C}$, mainly after $48 \mathrm{~h}$ out of water. Similar results were obtained by Handå et al. (2012) with Mytilus edulis, under different feeding regimes at 7 and $14{ }^{\circ} \mathrm{C}$. The maximum $\mathrm{O} / \mathrm{N}$ ratio was 45 , obtained with the most nutritious diet at $7{ }^{\circ} \mathrm{C}$. However, the use of $\mathrm{O} / \mathrm{N}$ ratio to determine the metabolic substrate should be done with caution as calculations may overestimate ammonia excretion and thereby lead to an $\mathrm{O} / \mathrm{N}$ ratio that is too low (Jokumsen and Fyhn 1982; Zwaan et al. 1983).

However, following the degradation of protein, if either the ammonia is used in a biosynthetic pathway or the amino acid carbon is utilised in gluconeogenesis, this will result in departures from these theoretical expectations for the $\mathrm{O} / \mathrm{N}$ ratio. This ratio can therefore provide a useful integration for understanding the level of activity of the oxidative and protein metabolism of the animal, but careful consideration must be given to the fates of the nitrogen and carbon that result from the breakdown of the proteins, especially considering that the mussels in this study were not fed.

The oxygen and ammonia results obtained are essential to calculate the necessary water flow through a holding or depuration system to keep oxygen saturation above a minimum limit. In the UK, the flow is set so as to keep oxygen above $5 \mathrm{mg} \mathrm{L}^{-1}$ or $50 \%$ saturation (Lee et al. 2008). Considering that the minimum oxygen is calculated by the authorities 
in $\mathrm{mg} \mathrm{L}^{-1}$ of wet weight, the following discussion uses these units.

According to the results obtained in this study and the worst case scenario of $15 \mu \mathrm{mol} \mathrm{g}^{-1} \mathrm{~h}^{-1}$ (dry flesh) or $30 \mathrm{mg} \mathrm{O}_{2} \mathrm{~kg}^{-1} \mathrm{~h}^{-1}$ (wet weight) oxygen consumption immediately after re-immersion at $11^{\circ} \mathrm{C}$ after $48 \mathrm{~h}$ out of water (Fig. 2), then the flow rate $\left(\mathrm{L} \mathrm{kg}^{-1} \mathrm{~h}^{-1}\right)$ can be estimated using the following formula:

$$
\begin{aligned}
\text { Flow rate }= & 2(\text { Oxygen consumption rate } / \text { Oxygen } \\
& \text { concentration of the water inlet }),
\end{aligned}
$$

where the oxygen concentration of the inflowing water should be above $90 \%$ saturation. By using the formula in a system with inflow water at $11{ }^{\circ} \mathrm{C}$ and $90 \%$ saturation (giving $8 \mathrm{mg} \mathrm{O}_{2} \mathrm{~L}^{-1}$ ) the minimum flow should be $8 \mathrm{~L} \mathrm{~kg}^{-1}$ live mussels $h^{-1}$. However, this calculated flow rate is much less than those recommended by UK authorities, which is $20 \mathrm{~L} \mathrm{~kg}^{-1} \mathrm{~h}^{-1}$ for systems consisting of a bulk bin with $250 \mathrm{~kg}$ of mussels (Lee et al. 2008). A recent field study by the authors (data not published) demonstrated that a flow of $10 \mathrm{~L} \mathrm{~h}^{-1} \mathrm{~kg}^{-1}$ is sufficient to keep oxygen saturation at $80 \%$ and $7 \mathrm{mg} \mathrm{L}^{-1} \mathrm{O}_{2}$ in a bulk bin system with $250 \mathrm{~kg}$ of mussels at $12.6{ }^{\circ} \mathrm{C}$ for $42 \mathrm{~h}$. This has tremendous implications for energy costs related to pumping. If the water flow can be reduced by half, then the energy of pumping water through the system is much reduced, thus decreasing costs and the carbon footprint.

On the other hand, water flow can also be calculated to ensure ammonia levels are maintained at an acceptable level in a holding or depuration system. This is largely dependent on two factors: the amount of ammonia being added to the system and the specific safe level (SSL) of ammonia to be maintained. Typically, in commercial depuration/holding recirculation systems, there are no biofilters, so the amount of ammonia being added to the system is the result of the build-up of ammonia excreted by the mussels, although the bacterial degradation of organic material (e.g., pseudofaeces) would also add to the ammonia load (Crear 2003).

However, the specific safe level (SSL), which is the concentration of ammonia that does not affect growth, has not yet been determined for M. edulis. The SSL is species dependent and abalone and sea bream are known to be very sensitive, 1 and $1.4 \mathrm{mg} \mathrm{L}^{-1}$ ammonia, respectively (Harris et al. 1998). Spiny lobsters tolerate up to $2 \mathrm{mg} \mathrm{L}^{-1}$ (Crear 2003), but bivalves are known to be very resistant to ammonia. The sublethal toxic concentration of ammonia in both Crassostrea virginica and Mercenaria mercenaria is $7.2 \mathrm{mg} \mathrm{L}^{-1}$ (Epifanio and Srna 1975). The $96 \mathrm{~h}$ lethal concentration causing 50\% mortality (LC50) of the green mussel Perna viridis was found to be as high as $2 \mathrm{~g} \mathrm{~L}^{-1}$ (Reddy and Menon 1979). Sadok et al. (1995) reported that M. edulis can survive acute exposure (up to $10 \mathrm{~h}$ ) to ambient ammonia levels at least as high as $7 \mathrm{~g} \mathrm{~L}^{-1}$.

By taking the LC50 for $P$. viridis and estimating the safe level for M. edulis by multiplying a factor of 0.1 , a method that has been used by previous authors (McKinney and Wade 1996; Mummert et al. 2003) for other species, then the hypothetical total ammonia concentration that gives a safe level is approximately $0.2 \mathrm{~g} \mathrm{~L}^{-1}$. If we again consider the worst case scenario, the ammonia excretion measured immediately after re-immersion at $15^{\circ} \mathrm{C}$ after $48 \mathrm{~h}$ of simulated transport is $2.8 \mu \mathrm{mol} \mathrm{g}^{-1} \mathrm{~h}^{-1}$ (dry flesh) equivalent to $2.1 \mathrm{mg} \mathrm{kg}^{-1} \mathrm{~h}^{-1}$, then the total ammonia excretion of $250 \mathrm{~kg}$ of mussels would amount to $0.53 \mathrm{~g}$ per hour. By using these numbers and the following formula, we can calculate the water flow rate that ensures the ammonia concentration is maintained at an acceptable level:

\section{Flow rate $=$ TAN excretion rate $/$ Specific "safe" level TAN TAN : total ammonia nitrogen}

The flow rate obtained equals $2.7 \mathrm{~L} \mathrm{~h}^{-1}$, showing that water flow does not need to be very high to ensure ammonia build-up is kept under control, as long as the specific safe level is $0.2 \mathrm{mg} \mathrm{L}^{-1}$.

\section{Conclusion}

In this study, specific trials were designed to simulate postharvest practices in the live mussel industry. These were essential to systematically determine the necessary water flow to keep oxygen levels above $50 \%$ saturation, and ammonia within safe levels in holding systems at different water temperatures. It was concluded that, even though ammonia excretion is more variable than oxygen under different post-harvest conditions, the optimal water flow to maintain a healthy and safe environment for holding mussels is mainly dependent on oxygen needs and water temperature. In this study, the highest calculated flow $\left(9 \mathrm{~L} \mathrm{~kg}^{-1}\right.$ live mussels $\mathrm{h}^{-1}$ at $\left.15^{\circ} \mathrm{C}\right)$ is lower than the depuration specifications in the UK $\left(20 \mathrm{~L} \mathrm{~kg}^{-1} \mathrm{~h}^{-1}\right)$. However, this information should be used with caution and further studies are necessary to validate the best water flow for different water temperatures in an industry-scale holding system.

Acknowledgements. This study was supported by The European Commission through the FP7 Research Framework Programme under grant agreement No. 243452 "MusselsAlive: Development of best practice and new technology for grading, handling, transportation, conditioning and storage of mussels for SMEs in the European mussel industry". The authors are also grateful to Dr. Purazen Chingombe for carrying out water analyses.

\section{References}

Almeida C., Soares F., 2012, Microbiological monitoring of bivalves from the Ria Formosa Lagoon (south coast of Portugal): A 20 years of sanitary survey. Mar. Pollut. Bull. 64, 252-262.

Bayne B., 1973, Aspects of the metabolism of Mytilus edulis during starvation. Neth. J. Sea Res. 7, 399-410.

Bayne B.L., 1976, Marine mussels: their ecology and physiology. Cambridge, Cambridge University Press.

Bayne B.L., Scullard C., 1977, Rates of nitrogen excretion by species of Mytilus edulis L. J. Mar. Biol. Assoc. UK 57, 371-378.

Boyden C.R., 1972, Aerial respiration of the cockle Cerastoderma edule in relation to temperature J. Comp. Biochem. Physiol. 43A, 697-712.

Bradley C.B., Grant A., 2002, Optimizing water quality O2. Technical report series The Tasmanian Aquaculture and Fisheries Institute, University of Tasmania. 
CEFAS, 2012, Classification and microbiological monitoring of bivalve molluscs in England and Wales. Centre for Environment, Fisheries \& Aquaculture Science, http://www.cefas.defra.gov.uk.

Chandurvelan R., Marsden I.D., Gaw S., Glover C.N., 2013, Fieldto-laboratory transport protocol impacts subsequent physiological biomarker response in the marine mussel, Perna canaliculus. Comp. Biochem. Physiol. Part A 164, 84-90.

Coleman N., 1973, The oxygen consumption of Mytilus edulis in air. Comp. Biochem. Physiol. Part A 45, 393-402.

Crear B.J., 2003, Recirculating systems for holding rock lobsters. In: Crear B.J., Cobcroft J.M., Battaglene S.C. (Eds.) Guide for the rock lobster industry, Tasmanian Aquaculture and Fisheries Institute.

Dare P.J., 1974, Damage caused to mussels (Mytilus edulis L.) by dredging and mechanized sorting. J. Cons. Int. Explor. Mer 35, 296-299.

de Vooys C.G.N., de Zwaan A., 1978, The rate of oxygen consumption and ammonia excretion by $M$. edulis after various periods of exposure to air. Comp. Biochem. Physiol. 60A, 343-347.

Epifanio C.E., Srna R.F., 1975, Toxicity of ammonia, nitrite ion, nitrate ion, and orthophosphate to Mercenaria mercenaria and Crassostrea virginica. Mar. Biol. 33, 241-246.

FAO, 2012, The state of world fisheries and aquaculture 2012. Food and Agriculture Organization of the United Nations, Rome.

Fitzhenry T., Halpin P., Helmuth B., 2004, Testing the effects of wave exposure, site, and behaviour on intertidal mussel body temperatures: applications and limits of temperature logger design. Mar. Biol. 145, 339-349.

Gosling E., 2003, Bivalve molluscs: Biology, ecology and culture. First edition, Oxford, Fishing News Books.

Handå A., Nordtug T., Halstensen S., Olsen A.J., Reitan K.I., Olsen Y., Reinertsen H., 2012, Temperature-dependent feed requirements in farmed blue mussels (Mytilus edulis L.) estimated from soft tissue growth and oxygen consumption and ammonia-N excretion. Aquac. Res. 44, 645-656.

Harding J.M., Couturier C., Parsons G.J., Ross N.W., 2004, Evaluation of the neutral red assay as a stress response indicator in cultivated mussels (Mytilus spp.) in relation to post-harvest processing activities and storage conditions. Aquaculture 231, 315-326.

Harris J.O., Maguire G.B., Edwards S., Hindrum S.M., 1998, Effect of ammonia on the growth rate and oxygen consumption of juvenile greenlip abalone, Haliotis laevigata Donovan. Aquaculture 160, 259-272.

Helmuth B.S.T., Hofmann G.E., 2001, Microhabitats, thermal heterogeneity, and patterns of physiological stress in the rocky intertidal zone. Biol. Bull. 201, 374-384.

Honkoop P.J.C., Bayne B.L., Underwood A.J., Svensson S., 2003, Appropriate experimental design for transplanting mussels (Mytilus sp.) in analyses of environmental stress: an example in Sydney Harbour (Australia). J. Exp. Mar. Biol. Ecol. 297, 253-268.

Jansen H.M., Strand Ø., Verdegem M., Smaal A., 2012, Accumulation, release and turnover of nutrients (C-N-P-Si) by the blue mussel Mytilus edulis under oligotrophic conditions. J. Exp. Mar. Biol. Ecol. 416-417, 185-195.

Jokumsen A., Fyhn H.J., 1982, The influence of aerial exposure upon respiratory and osmotic properties of haemolymph from two intertidal mussels, Mytilus edulis L. and Modiolus modiolus L. J. Exp. Mar. Biol. Ecol. 61, 189-203.

Lee R., Lovatelli A., Ababouch L., 2008, Bivalve depuration: fundamental and practical aspects FAO Fisheries Technical Paper, 511, FAO, Rome.
Love D.C., Lovelace G.L., Sobsey M.D., 2010, Removal of Escherichia coli, Enterococcus fecalis, coliphage MS2, poliovirus, and hepatitis A virus from oysters (Crassostrea virginica) and hard shell clams (Mercenaria mercenaria) by depuration. Int. J. Food Microbiol. 143, 211-217.

Lucas J.S., Southgate P.C., 2012, Aquaculture farming aquatic animals and plants. 2nd edn., Blackwell Publishing.

Marsden I., Weatherhead M., 1998, Effects of aerial exposure on oxygen consumption by the New Zealand mussel Perna canaliculus (Gmelin, 1791) from an intertidal habitat. J. Exp. Mar. Biol. Ecol. 230, 15-29.

McKinney A.D., Wade D.C., 1996, Comparative response of Ceriodaphnia dubia and juvenile Anodonta imbecillis to pulp and paper mill effluents discharged to the Tennessee river and its tributaries. Environ. Toxicol. Chem. 15, 514-517.

Moon T., Pritchard A., 1970, Metabolic adaptations in verticallyseparated populations of Mytilus californianus Conrad. J. Exp. Mar. Biol. Ecol. 5, 79-90.

Mummert A.K., Neves R.J., Newcomb T.J., Cherry D.S., 2003, Sensitivity of juvenile freshwater mussels (Lampsilis fasciola, Villosa iris) to total and un-ionized ammonia. Environ. Toxicol. Chem. 22, 2545-2553.

Muniain-Mujika I., Girones R., Tofiño-Quesada G., Calvo M., Lucena F., 2002, Depuration dynamics of viruses in shellfish. Int. J. Food Microbiol. 77, 125-133.

Newell R.C., Branch G.M., 1980, The influence of temperature on the maintenance of metabolic energy balance in marine invertebrates Adv. Mar. Biol. 17, 329-396.

Oliveira J., Cunha A., Castilho F., Romalde J.L., Pereira M.J., 2011, Microbial contamination and purification of bivalve shellfish: Crucial aspects in monitoring and future perspectives - A minireview. Food Control 22, 805-816.

Pastoriza L., Bernárdez M., Sampedro G., Cabo M.L., Herrera J.J.R., 2004, Elevated concentrations of oxygen on the stability of live mussel stored refrigerated. Eur. Food. Res. Technol. 218, 415-419.

Prochazka K., Griffiths C.L., 1991, Factors affecting the shelf life of live cultured mussels. J. Shellfish Res. 10, 23-28.

Reddy C.R.K., Menon N.R., 1979, Effects of ammonia and ammonium on tolerance and byssogenesis in Perna viridis. Mar. Ecol. Prog. Ser. 1, 315-321.

Sadok S., Uglow R., Haswell S.J., 1995, Fluxes of haemolymph ammonia and free amino acids in Mytilus edulis exposed to ammonia. Mar. Ecol. Prog. Ser. 129, 177-187.

Sadok S., Uglow R.F., Haswell S.J., 1999, Some aspects of nitrogen metabolism in Mytilus edulis: effects of aerial exposure. Mar. Biol. 135, 297-305.

Shick J.M., Widdows J., E. G., 1988, Calorimetric studies of behaviour, metabolism and energetics of sessile intertidal animals. Am. Zool. 28, 161-181.

Slabyj B.M., Hinkle C., 1976, Handling and storage of blue mussels in shell. Res. Life Sci. 23, 13.

Widdows J., D. Johnson J., 1988, Physiological energetics of Mytilus edulis: scope for growth. Mar. Ecol. Prog. Ser. 46, 113-121.

Wyatt J., Kenny S., Hobbs K.D., Mills T., Marshall H.D., Murray H.M., 2013, The effect of extended wet-storage on the condition, physiology and stress response of cultured blue mussels (Mytilus edulis L. 1758) during summer and fall in northeastern Newfoundland. Aquaculture 372, 111-118.

Zwaan A., Bont A.M.T., Zurburg W., Bayne B.L., Livingstone D.R., 1983, On the role of strombine formation in the energy metabolism of adductor muscle of a sessile bivalve. J. Comp. Physiol. B 149, 557-563. 